\title{
Response of Crop Water Requirement and Yield of Irrigated Rice to Elevated Temperature in Bangladesh
}

\author{
Md. Belal Hossain $(\mathbb{D}),{ }^{1}$ Debjit Roy ${ }^{D},{ }^{1}$ Md. Maniruzzaman $\left(\mathbb{D},{ }^{1}\right.$ Jatish Chandra Biswas $\left(\mathbb{D},{ }^{2}\right.$ \\ Umme Aminun Naher $\mathbb{D}{ }^{2}$ Md. Mozammel Haque $\mathbb{D}^{\mathbb{D}},{ }^{2}$ and Naveen Kalra $\mathbb{D}^{3}$ \\ ${ }^{1}$ Irrigation and Water Management Division, Bangladesh Rice Research Institute, Gazipur, Bangladesh \\ ${ }^{2}$ Soil Science Division, Bangladesh Rice Research Institute, Gazipur, Bangladesh \\ ${ }^{3}$ Department of Systems Design Engineering, University of Waterloo, Ontario, Canada
}

Correspondence should be addressed to Md. Belal Hossain; belal.iwm@gmail.com

Received 31 March 2021; Revised 20 June 2021; Accepted 24 June 2021; Published 7 July 2021

Academic Editor: Mathias N. Andersen

Copyright (c) $2021 \mathrm{Md}$. Belal Hossain et al. This is an open access article distributed under the Creative Commons Attribution License, which permits unrestricted use, distribution, and reproduction in any medium, provided the original work is properly cited.

\begin{abstract}
In the changing climatic condition, temperature is the most vulnerable parameter and is projecting a trend of increase in the future. Crop growth and development process depend largely on air temperature. This study aims to determine the role of increasing air temperature in yield, crop water requirement (CWR), and other agronomic parameters of irrigated rice. Ceres-rice model associated in the Decision Support System for Agrotechnology Transfer (DSSAT) was used in 15 different locations of Bangladesh. Grain yield, growth duration, and crop water requirement of widely cultivated irrigated rice (Boro rice) variety BRRI dhan 28 were analysed in normal temperature and elevated air temperature by $1^{\circ} \mathrm{C}, 2^{\circ} \mathrm{C}, 3^{\circ} \mathrm{C}$, and $4^{\circ} \mathrm{C}$. The result revealed detrimental effect of elevated temperature on growth duration and grain yield. The estimated highest growth duration reduction of 30 days was found in Moulvibazar for $4^{\circ} \mathrm{C}$ temperature rise. The grain yield reduction was projected by $0-17 \%, 16-35 \%, 31-49 \%$, and $39-61 \%$ from the normal condition if the seasonal mean temperature increased by $1^{\circ} \mathrm{C}, 2^{\circ} \mathrm{C}, 3^{\circ} \mathrm{C}$, and $4^{\circ} \mathrm{C}$, respectively. The country average crop water requirement was found to be $405 \mathrm{~mm}$ of which the highest $445 \mathrm{~mm}$ and the lowest $358 \mathrm{~mm}$ were recorded in Moulvibazar and Chandpur, respectively. The study revealed that the country average rice CWR reduced by $5 \%, 8 \%$, $12 \%$, and $17 \%$ over the normal condition for $1^{\circ} \mathrm{C}, 2^{\circ} \mathrm{C}, 3^{\circ} \mathrm{C}$, and $4^{\circ} \mathrm{C}$ rising temperature, respectively. For $1^{\circ} \mathrm{C}$ temperature rise, BRRI dhan 28 life span shortened by 6.4 days, grain yield reduced by $695 \mathrm{~kg}$, and estimated CWR decreased by $14 \mathrm{~mm}$. The projected declining CWR indicated that irrigated rice will require less irrigation water, but it will cause considerable yield loss under elevated temperature. Though elevated temperature will save huge irrigation water used in country-wide Boro rice cultivation, the crop developers need to introduce new heat-tolerant cultivar to minimize yield loss.
\end{abstract}

\section{Introduction}

Air temperature is the elementary environmental factor that regulates plant growth and development process. Both seasonal and annual potential evapotranspiration $\left(\mathrm{ET}_{0}\right)$ were linearly affected by maximum and minimum air temperature [1]. Crop life span mainly depends on accumulated growing degree days (GDD) and is derived from mean daily temperature over base temperature of crop. Besides, grain yield of crop largely depends on air temperature. Intergovernmental panel for climate change (IPCC) projected rising temperature by $1.5^{\circ} \mathrm{C}$ for $\mathrm{RCP} 4.5$ and $2^{\circ} \mathrm{C}$ for RCP 8.5 by the end of the $21^{\text {st }}$ century, relative to the average from the year 1850 to 1900 [2]. A historical (1990-2011) analysis showed increasing trend of daily average temperature in Northwest hydrological region of Bangladesh [3].

In recent days, climate change has been a worldwide concern. Bangladesh is facing climate change challenges for adequate cultivable land, irrigation water availability in dry season, groundwater level depletion, salinity intrusion in river and lands, excessive drought, erratic rainfall distribution, and so forth [4-7]. Around the world, researchers 
are continuously trying to understand the effect of climate change on irrigated crop cultivation [8-12]. Various studies predicted a considerable increase in irrigation water demand (10-25 percent) in rice cultivation in different climate change scenarios [8,13-19]. However, this high demand for irrigation water due to climate change will most likely bring water shortage or water availability crisis in north-western and southern part of Bangladesh. Already in north-western part of Bangladesh, groundwater level is declining rapidly due to excessive withdrawal for irrigation in dry season and to mitigate the drought [20]. Bangladeshi districts of Rajshahi, Pabna, Rangpur, Bogura, and Dinajpur are experiencing fast groundwater level depletion and huge shortage of irrigation water due to lack of adequate rainfall recharge [21]. In southern part of Bangladesh, in both tidal nonsaline and saline regions, the major rivers like Boleshwar, Burishwar, Tetulia, and Biskhali are the main sources of irrigation water. However, the availability of irrigation water is declining due to increase in river and adjacent canal water salinity [22, 23].

Bangladesh crop agriculture is considerably dominated by rice cultivation. Considering all rice growing season in Bangladesh, dry season rice (Boro rice) has the maximum share (53 percent) in total rice production [24]. As a major crop in dry season, Boro rice is fully dependent on irrigation, mostly from the month of January to May, because Boro rice gets a small portion of total annual rainfall in Bangladesh between January and May [7]. One of the major issues for Bangladesh agriculture is the variation in crop water requirement due to climate change in dry season. IPCC [25] projected that climate change will cause temperature increase and uneven rainfall distribution pattern in Bangladesh. Elevated temperature will change evapotranspiration as well as rice growing period length. High temperature will create the increased demand of evapotranspiration. Excess irrigation water supply in the rice field will be required to mitigate that demand. Consequently, rice plant physiology will be changed due to increased temperature and it will shorten the rice growth duration. The short growth span will reduce the number of irrigation days in rice field. However, rice crop is sensitive to temperature during its critical stages and increased temperature above the optimum may reduce yield drastically [26]. Maniruzzaman et al. [24] noticed yield loss and reduced growth duration of irrigated rice (Boro) in elevated air temperature over normal temperature in Bangladesh.

So, a comprehensive analysis of crop water requirement of rice in case of rising temperature, including potential evapotranspiration and irrigated rice growth duration, is necessary to understand the impacts of elevated temperature on irrigated rice cultivation for future planning and management of Bangladesh water resources. In this regard, this study was undertaken to determine the effect of elevated air temperature on crop water requirement and grain yield of irrigated rice.

\section{Materials and Methods}

2.1. Study Area. The study area covered fifteen locations representing the whole Bangladesh (Figure 1). The country has diversified climate around the year and soil condition. The climate of Bangladesh can be categorized into three distinct seasons, the winter (November to February), the hot summer premonsoon (March to May), and the monsoon (June to October) [27]. December to May is the suitable period for Boro rice cultivation. The maximum air temperature during Boro season varied from 28.4 to $31.6^{\circ} \mathrm{C}$ with the highest in Rajshahi and the lowest in Rangpur region (Table 1). The minimum air temperature ranged from $16.8^{\circ} \mathrm{C}$ in Rangpur and Moulvibazar to $19.6^{\circ} \mathrm{C}$ in Patuakhali region. The highest normal rainfall during Boro season was observed in Moulvibazar $(770 \mathrm{~mm})$ and the lowest rainfall was in Rajshahi $(291 \mathrm{~mm})$.

2.2. DSSAT Model. This study utilized CERES-Rice model incorporated in DSSAT 4.7. The CERES-Rice model accounted weather, soil properties, and management practices on crop performance [28]. The model simulates agronomic yield, yield contributing parameters, nitrogen level, soil-water regimes, hydrological parameters, and so forth under varying managements and environments. It also simulates interaction effects among the varying managements and environments. This study adopted PenmanMonteith method [29] to calculated reference crop evapotranspiration, soil conservation service method for infiltration, leaf photosynthesis response curve for photosynthesis, and Ritchie water balance for hydrology.

\subsection{Data Collection and Model Parameterization.} Historical (1981 to 2017) daily weather data of maximum and minimum temperature, relative humidity, wind speed, sunshine hour, and rainfall of fifteen locations were collected from Bangladesh Meteorological Department (BMD). Data of soil physical properties including particle size distribution, bulk density, chemical properties like soil organic carbon and nitrogen, and so forth were collected from Soil Resource Development Institute (SRDI) and are presented in Table 2. All these data were used as input to the model. Daily weather files and soil files were created in the DSSAT model. Major agronomic management inputs to the model are presented in Table 3. For the current study, planting date of 1 December 2015 and seedling age of 45 days were used for all 15 locations in model simulation. Nitrogen fertilizer (in the form of urea) was applied at 15 days after transplanting (DAT), $30 \mathrm{DAT}$, and $45 \mathrm{DAT}$ according to BRRI recommendation. When standing water disappeared from the field surface, irrigation was applied at the rate of $50 \mathrm{~mm}$.

2.4. Model Calibration and Validation. The tested cultivar BRRI dhan28 is short duration variety of Boro season developed by Bangladesh Rice Research Institute (BRRI). It usually takes 145 days to complete the life cycle [30]. The cultivar coefficient of BRRI dhan 28 was taken from Maniruzzaman et al. [31]. The genetic coefficient values of default cultivar BR14 were selected from the DSSAT genotype list (Table 4). The sensitive parameters (Table 4) of the tested 


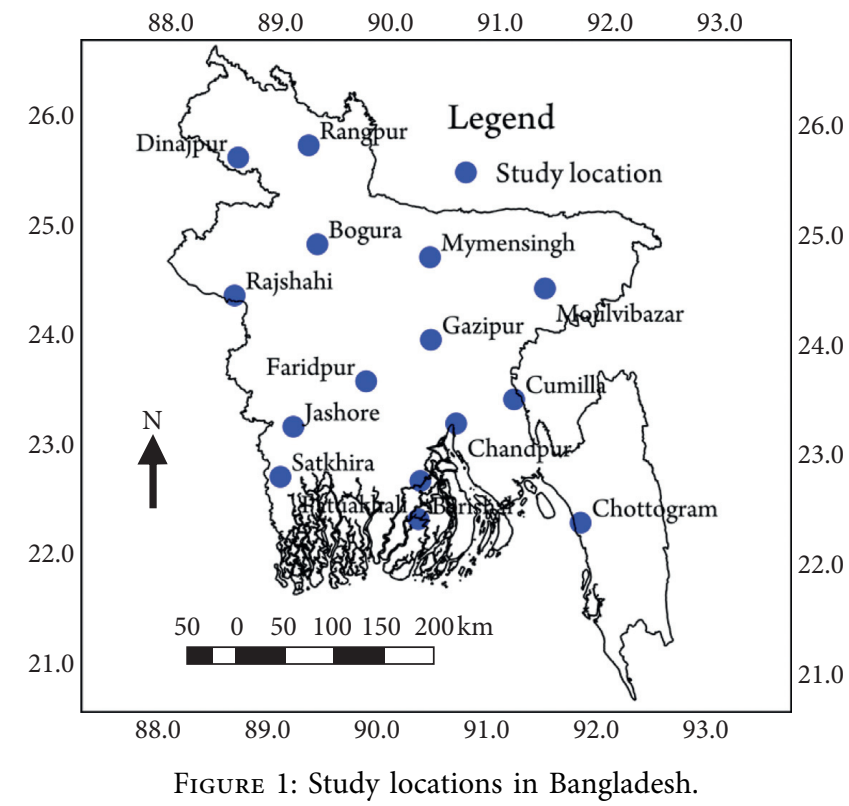

TABLE 1: Seasonal (December-May) normal weather (1981-2016) of the study locations.

\begin{tabular}{|c|c|c|c|c|}
\hline District & Maximum temperature $\left({ }^{\circ} \mathrm{C}\right)$ & Minimum temperature $\left({ }^{\circ} \mathrm{C}\right)$ & Mean temperature $\left({ }^{\circ} \mathrm{C}\right)$ & Rainfall (mm) \\
\hline Barishal & 30.9 & 18.5 & 24.7 & 408 \\
\hline Patuakhali & 30.2 & 19.6 & 24.9 & 481 \\
\hline Chandpur & 29.5 & 19 & 24.3 & 517 \\
\hline Chottogram & 29.6 & 19.3 & 24.5 & 550 \\
\hline Cumilla & 29.5 & 18.8 & 24.2 & 542 \\
\hline Faridpur & 30.1 & 18.3 & 24.2 & 435 \\
\hline Gazipur & 30.6 & 18.3 & 24.9 & 310 \\
\hline Mymensingh & 29.2 & 18.3 & 23.8 & 518 \\
\hline Jashore & 31.2 & 18.2 & 24.7 & 328 \\
\hline Satkhira & 30.8 & 18.8 & 24.8 & 330 \\
\hline Bogura & 29.5 & 17.7 & 23.6 & 344 \\
\hline Rajshahi & 31.6 & 17.9 & 24.8 & 291 \\
\hline Dinajpur & 28.8 & 16.9 & 22.9 & 327 \\
\hline Rangpur & 28.4 & 16.8 & 22.6 & 444 \\
\hline Moulvibazar & 30 & 16.8 & 23.4 & 770 \\
\hline Range & $28.4-31.6$ & $16.8-19.6$ & $22.6-24.9$ & $291-770$ \\
\hline
\end{tabular}

TABLE 2: Physical and chemical properties of soil in the study locations.

\begin{tabular}{|c|c|c|c|c|c|}
\hline \multirow[t]{2}{*}{ Location } & \multicolumn{2}{|c|}{$\begin{array}{l}\text { Particle size } \\
\text { distribution }\end{array}$} & \multirow[t]{2}{*}{ Bulk density $\left(\mathrm{g} \mathrm{cc}^{-1}\right)$} & \multirow[t]{2}{*}{ Organic carbon (\%) } & \multirow[t]{2}{*}{$\%$ nitrogen } \\
\hline & $\%$ clay & $\%$ silt & & & \\
\hline Barishal & 34 & 59 & 1.26 & 1.26 & 0.14 \\
\hline Patuakhali & 43 & 39 & 1.23 & 0.9 & 0.09 \\
\hline Chandpur & 13 & 49 & 1.29 & 0.53 & 0.05 \\
\hline Chottogram & 35 & 40 & 1.43 & 1.21 & 0.14 \\
\hline Cumilla & 46 & 42 & 1.36 & 0.14 & 0.01 \\
\hline Faridpur & 21 & 49 & 1.26 & 0.82 & 0.08 \\
\hline Gazipur & 34 & 47 & 1.43 & 1.21 & 0.14 \\
\hline Mymensingh & 19 & 53 & 1.26 & 0.4 & 0.05 \\
\hline Jashore & 21 & 49 & 1.26 & 0.82 & 0.08 \\
\hline Satkhira & 68 & 30 & 1.08 & 1.2 & 0.12 \\
\hline Bogura & 5 & 49 & 1.24 & 0.22 & 0.03 \\
\hline Rajshahi & 28 & 33 & 1.38 & 0.78 & 0.09 \\
\hline Dinajpur & 16 & 23 & 1.49 & 0.49 & 0.05 \\
\hline Rangpur & 17 & 54 & 1.29 & 0.94 & 0.08 \\
\hline Moulvibazar & 29 & 41 & 1.23 & 1.03 & 0.1 \\
\hline
\end{tabular}


TABLE 3: Crop management options as input to DSSAT model.

\begin{tabular}{lc}
\hline Management practices & Method/time of application \\
\hline Planting method & Transplanting \\
Planting distribution & Hills \\
Row distance & $20 \mathrm{~cm}$ \\
Number of seedlings hill & 3 \\
Urea fertilizer dose & 120 kg-N at three equal split applications \\
Irrigation method & Flood depth \\
\hline
\end{tabular}

TABLE 4: Genetic coefficient calibration of BRRI dhan28 for Bangladesh condition.

\begin{tabular}{|c|c|c|c|}
\hline Parameter & Meaning & $\begin{array}{l}\text { Default } \\
\text { (BR14) }\end{array}$ & $\begin{array}{c}\text { BRRI } \\
\text { dhan28 }\end{array}$ \\
\hline $\mathrm{P} 1$ & $\begin{array}{c}\text { Time period in GDD (growing degree days) in }{ }^{\circ} \mathrm{C} \text { above a base temperature from seedling emergence } \\
\text { during which the rice plant is not responsive to changes in photoperiod }\end{array}$ & 560 & 825 \\
\hline $\mathrm{P} 2 \mathrm{O}$ & $\begin{array}{c}\text { Critical photoperiod or the longest day length (in hours) at which the development occurs at } \\
\text { a maximum rate }\end{array}$ & 11.5 & 12.6 \\
\hline $\mathrm{P} 2 \mathrm{R}$ & $\begin{array}{l}\text { Extent to which phasic development leading to panicle initiation is delayed (expressed as GDD in }{ }^{\circ} \mathrm{C} \text { ) } \\
\text { for each hour increase in photoperiod above P2O }\end{array}$ & 200 & 150 \\
\hline P5 & Time period in GDD ${ }^{\circ} \mathrm{C}$ from beginning of grain filling to physiological maturity & 500 & 425 \\
\hline G1 & $\begin{array}{l}\text { Potential spikelet number coefficient as estimated from the number of spikelets per } g \text { of main culm dry } \\
\text { weight }\end{array}$ & 45 & 50 \\
\hline G2 & Single grain weight $(g)$ under ideal growing conditions & 0.026 & 0.022 \\
\hline G3 & Tillering coefficient (scalar value) relative to IR64 cultivar & 1.0 & 1.0 \\
\hline G4 & Temperature tolerance coefficient & 1.0 & 1.0 \\
\hline
\end{tabular}

cultivars were adjusted considering the observed grain yield and growth duration.

The model was calibrated with known grain yield and growth duration of "time of transplanting" experiment conducted at BRRI farm, Gazipur, during Boro, 2014-15. The genetic coefficient was calibrated considering the observed and simulated grain yield of the cultivar. The model validation used known values of grain yield and growth duration of BRRI dhan 28 from a multilocation trail conducted in the same year. For calibration and validation, the model predicted results were compared with field observed values. The model performance was analysed with normalized root mean square error (nRMSE), prediction error $\left(P_{e}\right)$, coefficient of determination $\left(R^{2}\right)$, and degree of agreement $(d)$. The equations are given as follows:

$$
\begin{aligned}
\text { nRMSE } & =\frac{1}{\bar{O}} \sqrt{\frac{\sum_{1}^{n}\left(P_{i}-O_{i}\right)^{2}}{N}} \times 100, \\
P_{e} & =\frac{\left(P_{i}-O_{i}\right)}{O_{i}} \times 100, \\
R^{2} & =\left[\frac{\sum\left(O_{i}-\bar{O}\right)\left(P_{i}-\bar{P}\right)}{\sqrt{\sum\left(O_{i}-\bar{O}\right)^{2} \sum\left(P_{i}-\bar{P}\right)^{2}}}\right]^{2}, \\
d & =1-\frac{\sum_{i=1}^{N}\left(P_{i}-O_{i}\right)^{2}}{\sum_{i=1}^{N}\left(\left|P_{i}-\bar{O}\right|+\left|O_{i}-\bar{O}\right|\right)^{2}} .
\end{aligned}
$$

The coefficient of determination $\left(R^{2}\right)$ ranges from 0 to 1 in which values close to 1 indicate a good agreement and values greater than 0.5 are considered acceptable in watershed simulations [32]. In case of nRMSE, a simulation can be considered excellent if nRMSE is smaller than $10 \%$, good if between 10 and $20 \%$, fair if between 20 and $30 \%$, and poor if larger than $30 \%$ [33]. The magnitude of $P_{e}(\%)$ is expected to be less than $15 \%$, indicating the good performance of the model [34]. The values of $d$ range between 0 and 1, where 0 indicates no agreement and 1 indicates a perfect agreement between predicted and observed data [35].

\subsection{Simulation of Growth Duration, Crop Water Requirement,} Grain Yield, and Water Productivity. The model simulated grain yield and agronomic parameters for 15 individual study locations for the base year Boro, 2014-15, following normal condition. To do this, multilocation trial crop management files were created using the respective soil and weather files of the stations. Impact of elevated air temperature on yield and phenology was determined using environment modification tools by adding $1^{\circ} \mathrm{C}, 2^{\circ} \mathrm{C}, 3^{\circ} \mathrm{C}$, and $4^{\circ} \mathrm{C}$ with observed maximum and minimum temperatures of 2014-2015 of each study station. The actual water productivity $\left(\mathrm{ET}_{c}\right.$ based) was calculated considering grain yield and crop evapotranspiration using the following equation:

$$
\mathrm{WP}_{\mathrm{ET}}=\frac{\text { grain yield }}{\mathrm{ET}_{c} \times 10},
$$


where water productivity is in $\mathrm{kg} \mathrm{m}^{-3}$, grain yield is in $\mathrm{kg}$ $\mathrm{ha}^{-1}$, and $\mathrm{ET}_{c}$ is in $\mathrm{mm}$.

\section{Results and Discussion}

3.1. Model Calibration. Table 5 represents model simulated and field observed grain yield as well as growth duration for default and tested cultivar under varying transplanting dates. For grain yield evaluation, BRRI dhan 28 showed better agreement between simulated and observed values than default cultivar. In terms of model evaluating parameters $\left(P_{e}\right.$, nRMSE, $R^{2}$, and $d$ ), the values for BRRI dhan 28 were within the recommended limit compared to default cultivar. However, for growth duration assessment, other evaluating parameters of both cultivars were found within the recommended range except degree of agreement $(d)$ of default variety. Hence, the adjusted sensitive parameters of BRRI dhan 28 performed better regarding grain yield and growth duration compared to the default cultivar.

3.2. Model Validation. The CERES-Rice model was validated with simulated and observed data of grain yield and growth duration of multilocation trial during Boro, 2014-15 (Table 6). Excellent model validation was found with nRMSE values of 2.5 and $2.9, R^{2}$ values of 0.67 and 0.8 , and $P_{e}$ values of $0.7 \%$ and $13 \%$, for grain yield and for growth duration, respectively.

\subsection{Temporal Distribution of Reference Crop} Evapotranspiration. Reference crop evapotranspiration $\left(\mathrm{ET}_{o}\right)$ is the evapotranspiration under the given meteorological conditions from a reference surface (hypothetical grass reference crop, i.e., green, well-watered grass of uniform height, actively growing and completely shading the ground with an assumed crop height of $0.12 \mathrm{~m}$, a fixed surface resistance of $70 \mathrm{~s}$ $\mathrm{m}^{-1}$, and an albedo of 0.23) [29]. It provides an idea about atmospheric water demand and actual crop water requirement in a given meteorological condition. In Gazipur, $\mathrm{ET}_{o}$ showed rising trend from January and reached its peak in the month of May (Figure 2). After May, it tended to decrease over time and reached the minimum during December. This was the combined effect of mean temperature, bright sunshine hours, wind speed, and relative humidity. Increased $\mathrm{ET}_{o}$ occurred during March to May due to lower relative humidity and higher mean temperature. Less bright sunshine hours and high humidity caused the reduction in monthly $\mathrm{ET}_{o}$ in rainy season (June to October). On the contrary, in the other months (November to February), with low temperature, less wind speed, and reduced sunshine hours due to foggy weather, $\mathrm{ET}_{o}$ reached its minimum [36]. Seasonal (January to May, i.e., Boro season) $\mathrm{ET}_{o}$ showed the increasing trend over incremental temperature. Seasonal $\mathrm{ET}_{o}$ increased by $15,30,45$, and $58 \mathrm{~mm}$ for $1^{\circ} \mathrm{C}, 2^{\circ} \mathrm{C}$, $3^{\circ} \mathrm{C}$, and $4^{\circ} \mathrm{C}$ temperature rise, respectively.

\subsection{Temperature Effect on Growth Duration and Grain Yield.} Figure 3(a) analyses the crop growth duration response to mean seasonal temperature. It shows significant relationship between the two parameters. Growth duration of Boro rice decreased by 6.4 days per $1^{\circ} \mathrm{C}$ temperature rise. Maniruzzaman et al. [24] showed similar findings of 7.45 days' growth duration reduction of BRRI dhan 28 for $1^{\circ} \mathrm{C}$ temperature rise. Mahmud [37] also reported 7-8 days' growth duration reduction per $1^{\circ} \mathrm{C}$ temperature rise for BR23 cultivar. Spatial variation showed the highest growth duration of 155 days of BRRI dhan28 in Dinajpur with the lowest seasonal mean temperature of $21.1^{\circ} \mathrm{C}$ (Figure 4). The lowest growth duration of 131 days was observed in Chottogram, since it had the highest seasonal mean temperature of $23.3^{\circ} \mathrm{C}$. The country average growth duration of the tested cultivar was found to be 144 days with the mean temperature of $22^{\circ} \mathrm{C}$. Among the locations, the simulated growth duration reduced to $147,140,133$, and 128 days if temperature increased by $1^{\circ} \mathrm{C}$, $2^{\circ} \mathrm{C}, 3^{\circ} \mathrm{C}$, and $4^{\circ} \mathrm{C}$ from the base temperature in Dinajpur. Among the locations, the maximum growth duration reduction was reported in Moulvibazar. The growth duration was decreased by $11,18,23$, and 30 days for $1^{\circ} \mathrm{C}, 2^{\circ} \mathrm{C}, 3^{\circ} \mathrm{C}$, and $4^{\circ} \mathrm{C}$ temperature rise, respectively. On the other hand, the minimum growth duration reduction was found in Patuakhali. The growth duration was decreased by $5,10,15$, and 20 days for $1^{\circ} \mathrm{C}, 2^{\circ} \mathrm{C}, 3^{\circ} \mathrm{C}$, and $4^{\circ} \mathrm{C}$ temperature rise, respectively. Rising temperature accelerates the crop growth and development process, resulting in shortening the growth duration of irrigated rice [38]. However, growth duration contributes directly to the yield, but shorter life span due to rising temperature may affect the production in the future [24].

Elevated temperature affected directly the grain yield of tested variety BRRI dhan28. A highly significant $\left(R^{2}=0.86\right.$, $p<0.000)$ relation was found between temperature and grain yield. It showed that the grain yield of irrigated rice reduced by $695 \mathrm{~kg} \mathrm{ha}^{-1}(11.9 \%)$ per $1^{\circ} \mathrm{C}$ seasonal mean temperature rise (Figure 3(b)). Maniruzzaman et al. [24] reported $4.77 \%$ yield reduction for BRRI dhan 28 , whereas Mahmud [37] reported 9.7 to $22.7 \%$ decreased yield per $1^{\circ} \mathrm{C}$ temperature rise. Increase in global mean temperature would reduce the global rice yield by an average of 3.2\% [39]. The response of grain yield at normal and elevated air temperature is analysed and presented in Table 7. The highest simulated grain yield at normal temperature observed was $6346 \mathrm{~kg} \mathrm{ha}^{-1}$ in Moulvibazar, whereas the lowest grain yield was $4893 \mathrm{~kg} \mathrm{ha}^{-1}$ in Chandpur. The dissimilarity of grain yield could be explained by spatial variation of growth duration, as well as climate and soil properties. Since life span becomes shorter with the increasing temperature, it affects directly the grain yield. The highest $17 \%$ yield reduction was predicted in Mymensingh and Cumilla and no yield reduction was projected for Rangpur and Dinajpur regions with the $1^{\circ} \mathrm{C}$ temperature rise. A little yield loss $(<5 \%)$ was monitored in Gazipur and Moulvibazar region with the same scenarios. In case of $2^{\circ} \mathrm{C}$ temperature rise, 16 to $35 \%$ yield reduction was estimated, of which the highest reduction was found in Cumilla and the lowest in Rangpur region. The yield reduction ranged from 31 to $49 \%$ and from 39 to $61 \%$ from the normal condition if the seasonal mean temperature increased by $3^{\circ} \mathrm{C}$ and $4^{\circ} \mathrm{C}$, respectively. In another study, Rani and Maragatham [40] showed $13.3 \%$ and $23 \%$ grain yield reduction for $2^{\circ} \mathrm{C}$ and $4^{\circ} \mathrm{C}$ temperature rise 
TABLE 5: Statistical evaluation of observed and simulated yield and growth duration of BRRI dhan28 for different transplanting dates during 2014-15 at Gazipur for model calibration.

\begin{tabular}{|c|c|c|c|c|c|c|c|}
\hline \multirow{3}{*}{ Transplanting date } & \multirow{3}{*}{ Seasonal mean temperature ( $\underline{\mathrm{o}} \mathrm{C})$} & \multicolumn{3}{|c|}{ Grain yield $\left(\mathrm{kg} \mathrm{ha}^{-1}\right)$} & \multicolumn{3}{|c|}{ Growth duration (days) } \\
\hline & & \multirow{2}{*}{ Observed } & \multicolumn{2}{|c|}{ Simulated } & \multirow{2}{*}{ Observed } & \multicolumn{2}{|c|}{ Simulated } \\
\hline & & & Default & BRRI dhan 28 & & Default & BRRI dhan 28 \\
\hline 06 Jan. & 21.4 & 5740 & 3204 & 6156 & 138 & 125 & 137 \\
\hline 22 Jan. & 22.4 & 5020 & 3220 & 5502 & 133 & 123 & 133 \\
\hline 06 Feb. & 23.3 & 4770 & 3397 & 5017 & 130 & 121 & 128 \\
\hline 22 Feb. & 24.3 & 3970 & 3253 & 4402 & 126 & 117 & 121 \\
\hline$P_{e}(\%)$ & & & 31.7 & 8.2 & & 7.7 & 1.3 \\
\hline$R^{2}$ & & & 0.10 & 0.98 & & 0.94 & 0.96 \\
\hline nRMSE (\%) & & & 35.6 & 8.3 & & 7.8 & 2.1 \\
\hline$d$ & & & 0.34 & 0.90 & & 0.49 & 0.93 \\
\hline
\end{tabular}

TABLE 6: Statistical evaluation of observed and simulated yield and growth duration of BRRI dhan28 for multilocation trial during 2014-15 for model validation.

\begin{tabular}{|c|c|c|c|c|}
\hline \multirow{2}{*}{ Location } & \multicolumn{2}{|c|}{ Grain yield $\left(\mathrm{kg} \mathrm{ha}^{-1}\right)$} & \multicolumn{2}{|c|}{ Growth duration (days) } \\
\hline & Simulated & Observed & Simulated & Observed \\
\hline Rangpur & 5795 & 5830 & 154 & 150 \\
\hline Kushtia & 5803 & 5690 & 142 & 141 \\
\hline Rajshahi & 5475 & 5260 & 143 & 145 \\
\hline Satkhira & 5627 & 5800 & 139 & 140 \\
\hline Cumilla & 5771 & 5700 & 133 & 143 \\
\hline$P_{e}(\%)$ & \multicolumn{2}{|c|}{0.7} & \multicolumn{2}{|c|}{13} \\
\hline$R^{2}$ & \multicolumn{2}{|c|}{0.67} & \multicolumn{2}{|c|}{0.8} \\
\hline nRMSE (\%) & \multicolumn{2}{|c|}{2.5} & \multicolumn{2}{|c|}{2.9} \\
\hline$d$ & \multicolumn{2}{|c|}{0.82} & \multicolumn{2}{|c|}{0.76} \\
\hline
\end{tabular}

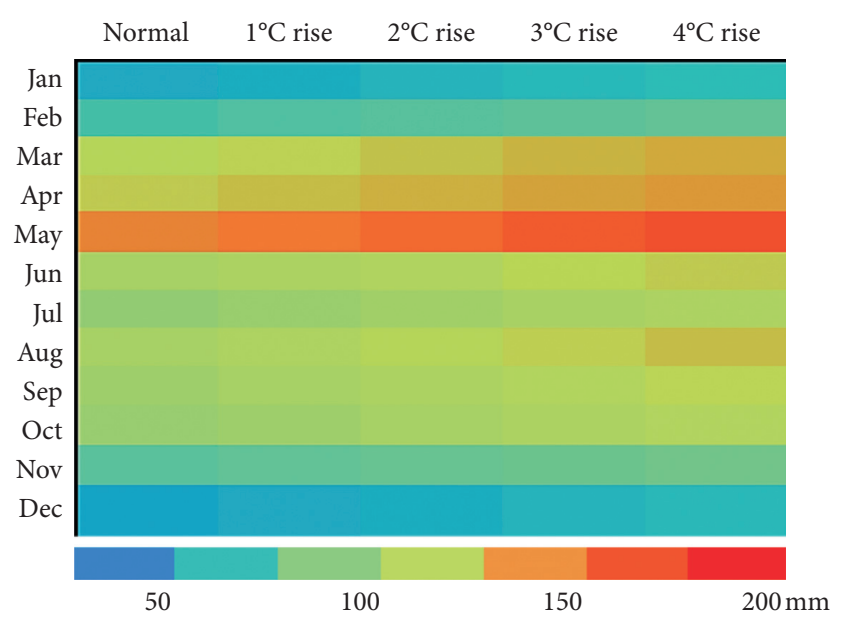

FIGURE 2: Change in monthly total reference crop evapotranspiration under climate change scenarios in Gazipur.

compared to ambient temperature of dry season rice in Tamil Nadu, India.

3.5. Crop Water Requirement of Irrigated Rice Affected by Elevated Temperature. Crop water requirement depends on climatic condition, types of crops, stage of crops, and life span of crop. Since large spatiotemporal variation (Table 8) was observed in Bangladesh, it affected directly the growth duration as well as seasonal crop water requirement of irrigated rice. Country average of $405 \mathrm{~mm}$ CWR was observed in Bangladesh during Boro, 2015, and the maximum $445 \mathrm{~mm}$ and the minimum $358 \mathrm{~mm}$ water demands were estimated in Moulvibazar and Chandpur, respectively. Shahid [7] showed $423 \mathrm{~mm}$ to $483 \mathrm{~mm}$ potential CWR of rice in north-western region of Bangladesh. Hossain et al. [36] showed an estimation of average $505 \mathrm{~mm}$ rice evapotranspiration of BRRI dhan 28 during Boro season having a growth duration of 150 days in north-western hydrological region of Bangladesh. Rising temperature showed the decreasing CWR over normal weather condition in all locations of Bangladesh. This was due to the cumulative effect of increasing evapotranspiration and decreasing crop growth duration. The country average of $5 \%$ CWR reduced from normal condition, and the biggest change $(-7 \%)$ was observed in Dinajpur. The minimum deviation $(-3 \%)$ was recorded in Faridpur, Chandpur, and Gazipur regions when mean temperature increased by $1^{\circ} \mathrm{C}$. Similarly, the projected country average CWR reduction ranged from 6 to $12 \%$, from 10 to $16 \%$ and from 13 to $23 \%$ for $2^{\circ} \mathrm{C}, 3^{\circ} \mathrm{C}$, and $4^{\circ} \mathrm{C}$ elevated temperature, respectively. The maximum $\mathrm{CWR}$ reduction was found in Moulvibazar at $2^{\circ} \mathrm{C}$ temperature rise, whereas Bogura region showed the maximum sensitivity at $3^{\circ} \mathrm{C}$ and $4^{\circ} \mathrm{C}$ rising scenarios.

This study identified that CWR was the resultant of seasonal mean temperature and growth duration. The high temperature increased the CWR but reduced the life span of crop, resulting in less water requirement. Seasonal CWR reduced by $14 \mathrm{~mm}$ per $1^{\circ} \mathrm{C}$ temperature rise in Bangladesh 


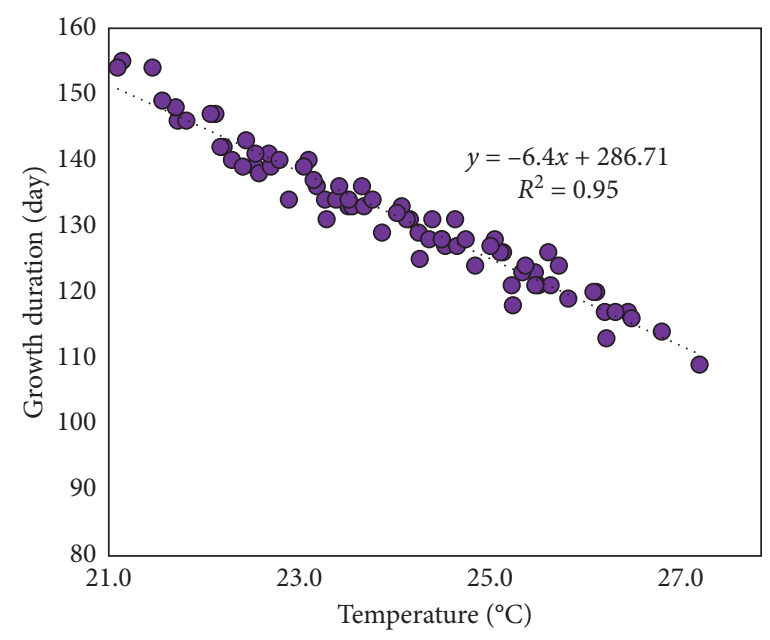

(a)

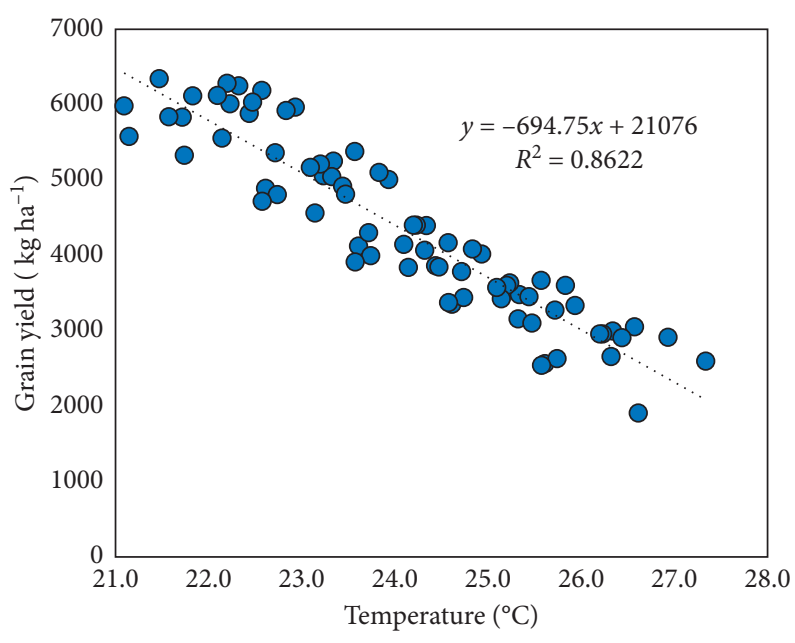

(b)

FIGURE 3: Interrelationship among seasonal mean temperature, growth duration, and grain yield for Boro rice in Bangladesh.

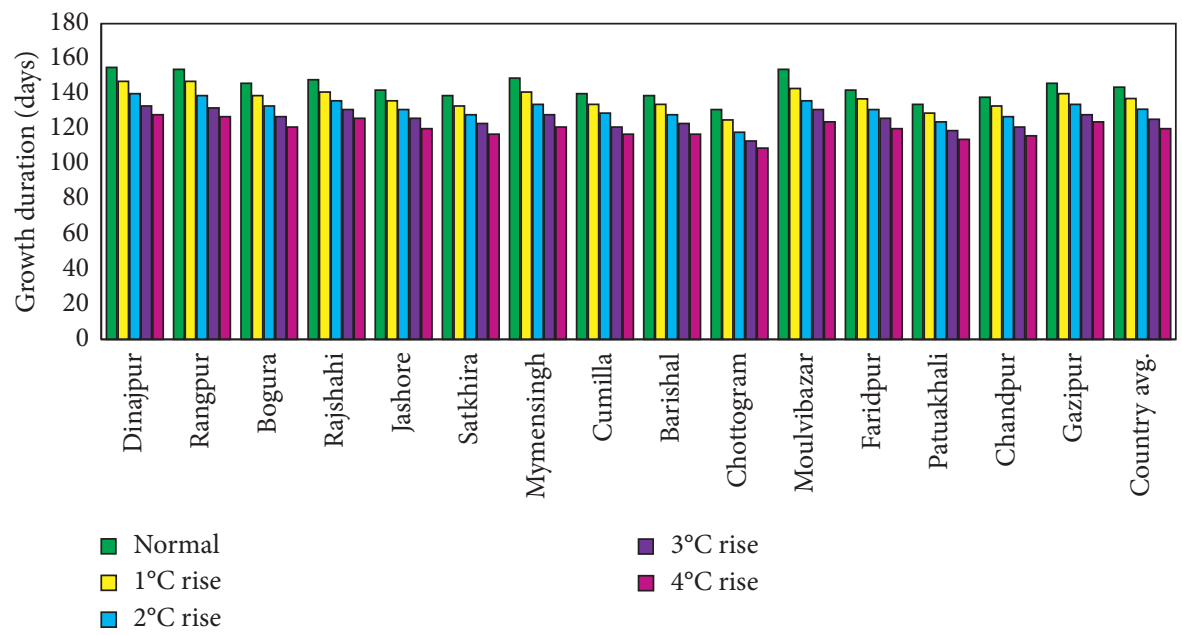

FIGURE 4: Spatial distribution of growth duration of BRRI dhan28 with different temperature rising scenarios.

Table 7: Percent yield deviation with the elevated air temperature in the study locations.

\begin{tabular}{|c|c|c|c|c|c|}
\hline \multirow{2}{*}{ Location } & \multirow{2}{*}{ Normal yield $\left(\mathrm{kg} \mathrm{ha}^{-1}\right)$} & \multicolumn{4}{|c|}{ Yield reduction (\%) } \\
\hline & & $1^{\circ}$ rise & $2^{\circ}$ rise & $3^{\circ}$ rise & $4^{\circ}$ rise \\
\hline Dinajpur & 5579 & 0 & 18 & 31 & 39 \\
\hline Rangpur & 6150 & 0 & 16 & 33 & 42 \\
\hline Bogura & 5330 & 10 & 25 & 35 & 51 \\
\hline Rajshahi & 5837 & 8 & 26 & 35 & 44 \\
\hline Jashore & 6011 & 16 & 27 & 40 & 51 \\
\hline Satkhira & 6191 & 13 & 33 & 41 & 51 \\
\hline Mymensingh & 5843 & 19 & 33 & 42 & 56 \\
\hline Cumilla & 6251 & 19 & 35 & 49 & 57 \\
\hline Barishal & 5886 & 16 & 34 & 41 & 51 \\
\hline Chottogram & 5252 & 16 & 34 & 43 & 51 \\
\hline Moulvibazar & 6346 & 5 & 24 & 39 & 51 \\
\hline Faridpur & 6286 & 17 & 30 & 43 & 53 \\
\hline Patuakhali & 5969 & 16 & 33 & 44 & 51 \\
\hline Chandpur & 4893 & 16 & 31 & 48 & 61 \\
\hline Gazipur & 6118 & 3 & 17 & 33 & 41 \\
\hline
\end{tabular}


TABLE 8: Change of crop water requirement (CWR) to temperature rise in Bangladesh.

\begin{tabular}{|c|c|c|c|c|c|}
\hline \multirow{2}{*}{ Location } & \multirow{2}{*}{ Normal CWR (mm) } & \multicolumn{4}{|c|}{$\%$ deviation of CWR over normal condition } \\
\hline & & $1^{\circ}$ rise & $2^{\circ}$ rise & $3^{\circ}$ rise & $4^{\circ}$ rise \\
\hline Dinajpur & 411 & -7 & -11 & -15 & -19 \\
\hline Rangpur & 426 & -5 & -9 & -13 & -17 \\
\hline Bogura & 361 & -6 & -10 & -16 & -23 \\
\hline Rajshahi & 406 & -5 & -8 & -11 & -15 \\
\hline Jashore & 405 & -5 & -7 & -11 & -15 \\
\hline Satkhira & 397 & -5 & -8 & -11 & -17 \\
\hline Mymensingh & 386 & -6 & -10 & -14 & -20 \\
\hline Cumilla & 408 & -5 & -8 & -15 & -18 \\
\hline Barishal & 409 & -3 & -7 & -10 & -15 \\
\hline Chottogram & 418 & -4 & -9 & -12 & -16 \\
\hline Moulvibazar & 445 & -8 & -12 & -15 & -20 \\
\hline Faridpur & 407 & -3 & -7 & -11 & -16 \\
\hline Patuakhali & 422 & -4 & -6 & -10 & -14 \\
\hline Chandpur & 358 & -3 & -8 & -14 & -18 \\
\hline Gazipur & 424 & -3 & -6 & -11 & -13 \\
\hline Country average & 405 & -5 & -8 & -12 & -17 \\
\hline
\end{tabular}

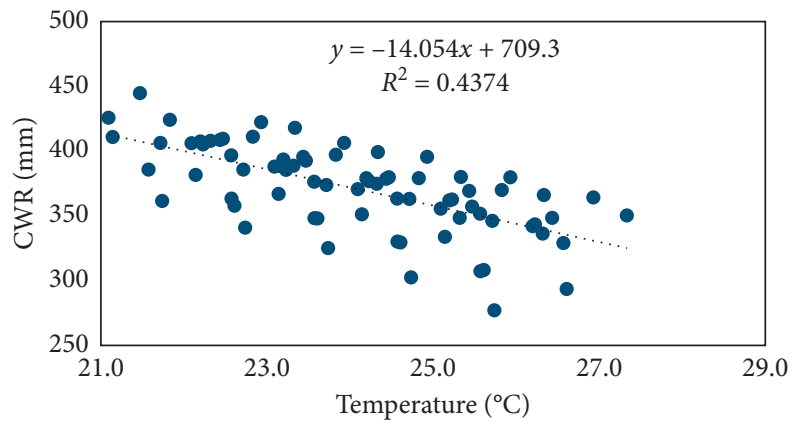

Figure 5: Temperature effect on seasonal crop water requirement in Bangladesh.

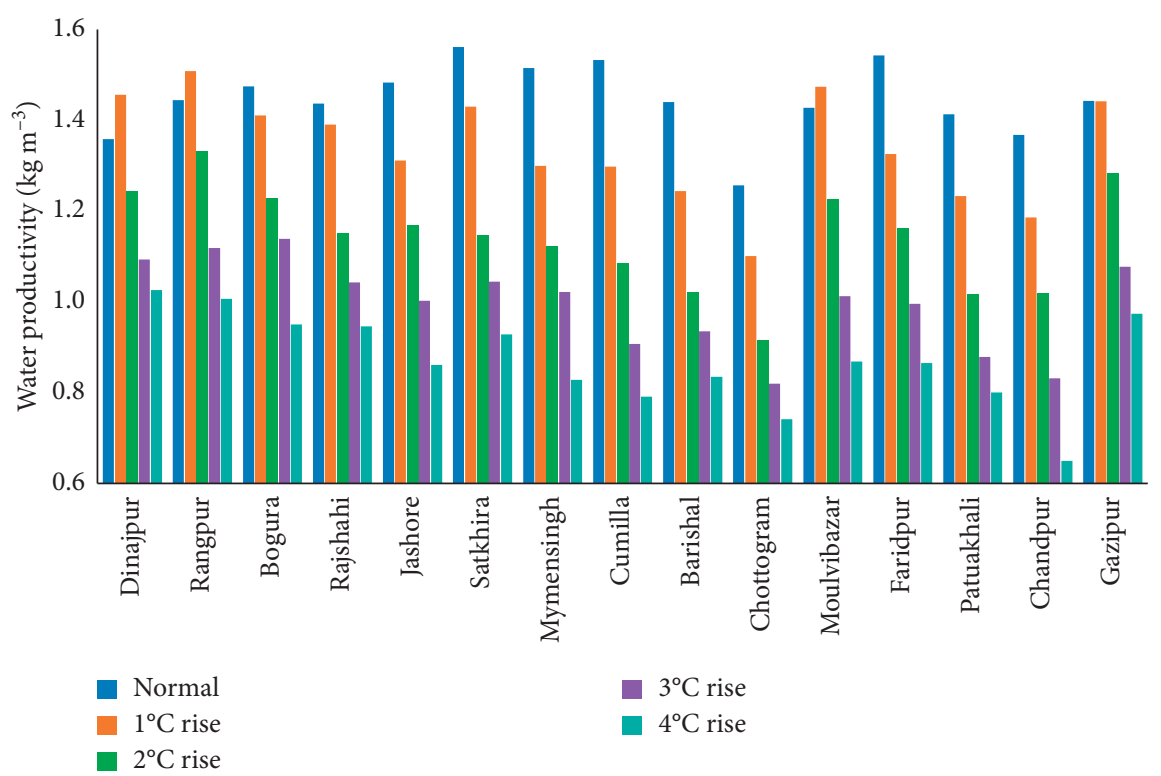

Figure 6: Actual water productivity of rice under elevated temperature in the study locations. 
(Figure 5). Acharjee et al. [4] also found a similar result and indicated that shorter growth duration due to higher temperature decreased potential crop water requirement of Boro rice. Higher crop water requirement demanded more irrigation water for crop production, since Boro rice grows completely in irrigated condition. Crop fulfils its water demand from either rainfall or irrigation. But Boro rice is typically in winter (December-January) and the crop lasts until premonsoon (April-May) season in Bangladesh. Dry season rice has more irrigation demand than the rice grown in other seasons. Reduced CWR will necessitate less irrigation requirement. Acharjee et al. [4] estimated 6.5-10.9\% reduced potential crop water requirement during Boro season for RCP 4.5 and 8.5 , respectively, for 2050s. They also reported $8.3 \%$ and $17.6 \%$ decreased crop water requirement by 2080 s for RCP 4.5 and 8.5 , respectively. This estimated reduction in CWR will reduce the irrigation cost as well as total cost of rice production. It also decreases fuel consumption used in irrigation pumps, which will minimize greenhouse gas emission to the environment. In Bangladesh, $76 \%$ of irrigation water comes from groundwater source [41]. Thus, minimized CWR will reduce groundwater abstraction.

3.6. Rice Water Productivity Affected by Elevated Temperature. Generally, actual water productivity $\left(\mathrm{WP}_{\mathrm{ET}}\right)$ decreased with the increase in mean air temperature (Figure 6). This was the result of reduced grain yield and $\mathrm{ET}_{c}$. Though both $\mathrm{ET}_{c}$ and grain yield were reducing in elevated temperature, decreased grain yield played the driving role of less $\mathrm{WP}_{\mathrm{ET}}$ in all the study locations. However, $\mathrm{WP}_{\mathrm{ET}}$ of Dinajpur, Rangpur, and Moulvibazar increased in $1^{\circ} \mathrm{C}$ temperature rise condition compared to the normal condition. This happened because the grain yield in $1^{\circ} \mathrm{C}$ temperature rise was similar to normal temperature. Dinajpur, Rangpur, and Moulvibazar are situated in cold tempered region. Due to this, the growth duration of the tested cultivar in $1^{\circ} \mathrm{C}$ temperature rise remained above the average growth duration (145 days).

\subsection{Carbon Dioxide $\left(\mathrm{CO}_{2}\right)$ Concentration Effect on Yield.} Mean surface temperature of Bangladesh is projected to rise by $2.0^{\circ} \mathrm{C}$ to $4.0^{\circ} \mathrm{C}$ according to Representative Concentrate Pathways (RCP) by the end of 2100 compared to the base years of 1986-2005 [2]. Carbon dioxide concentration will be increased as well [38]. The current study showed that the elevated temperature decreased grain yield and growth duration of the cultivar. However, increase in $\mathrm{CO}_{2}$ concentration compensates the grain yield lost by temperature rise [24]. Increased air $\mathrm{CO}_{2}$ level enhances photosynthesis and reduced respiration processes of crop and improves crop water use efficiency. Hence, the process contributes to crop yield $[42,43]$.

\section{Conclusion}

Elevated air temperature affected life span and grain yield of irrigated crop, but it reduced the seasonal crop water requirement that results in less irrigation demand for dry season rice cultivation. Elevated temperature shortened the crop growth duration and reduced the crop water requirement. In response, the reduced crop water requirement will decrease the irrigation demand and, consequently, the number of irrigation days. The combined effect of less irrigation demand and irrigation days will save huge amount of irrigation water currently required for dry season Boro rice cultivation in Bangladesh. However, the reduction in crop growing period due to temperature rise will cause substantial yield reduction of current rice cultivars. It would be a near-future challenge for crop developers to introduce a new type of cultivar which can tolerate the effect of elevated temperature with no significant yield loss. At present, Bangladesh is the 4th rice-growing country around the world and it contributes $7 \%$ of total rice production in the world [44]. Although many countries grow rice, Bangladesh is the most vulnerable country to climate change, especially temperature rise. Besides, water availability or scarcity is one of the crucial factors for dry season rice cultivation. Thus, in the present situation, there is dire need to investigate in detail the future rice water demand along with the rising temperature. This will help to plan irrigation strategies with limited water resources.

\section{Data Availability}

All data used to support the findings of this study are available from the corresponding author upon request.

\section{Disclosure}

The findings are the outcome of the collaborative research of Bangladesh Rice Research Institute (BRRI), Bangladesh Agricultural Research Institute (BARI), and Bangabandhu Sheikh Mujibur Rahman Agricultural University (BSMRAU).

\section{Conflicts of Interest}

The authors declare that they have no conflicts of interest.

\section{Acknowledgments}

The authors acknowledge the Modeling Climate Change on Agriculture Project (CRP-II, KGF) for funding this study.

\section{References}

[1] G. T. Patel and D. K. Singh, "Sensitivity of annual and seasonal reference crop evapotranspiration to principal climatic variables," Journal of Earth System Science, vol. 124, pp. 219-828, 2016.

[2] IPCC, "Summary for policymakers," in Climate Change 2013: The Physical Science Basis. Contribution of Working Group I to the Fifth Assessment Report of the Intergovernmental Panel on Climate Change, T. F. Stocker, D. Qin, G.-K. Plattner et al., Eds., Cambridge University Press, Cambridge, UK, 2013.

[3] M. A. Mojid, R. P. Rannu, and N. N. Karim, "Climate change impacts on reference crop evapotranspiration in North-West hydrological region of Bangladesh," International Journal of Climatology, vol. 35, no. 13, pp. 4041-4046, 2015. 
[4] T. K. Acharjee, G. V. Halsema, F. Ludwig, and P. Hellegers, "Declining trends of water requirements of dry season Boro rice in the north-west Bangladesh," Agricultural Water Management, vol. 180, pp. 148-159, 2017.

[5] M.-U. D. Ahmad, M. Kirby, M. S. Islam, M. J. Hossain, and M. M. Islam, "Groundwater use for irrigation and its productivity: status and opportunities for crop intensification for food security in Bangladesh," Water Resources Management, vol. 28, no. 5, pp. 1415-1429, 2014.

[6] G. S. A. Salem, S. Kazama, S. Shahid, and N. C. Dey, "Impact of temperature changes on groundwater levels and irrigation costs in a groundwater-dependent agricultural region in Northwest Bangladesh," Hydrological Research Letters, vol. 11, no. 1, pp. 85-91, 2017.

[7] S. Shahid, "Impact of climate change on irrigation water demand of dry season Boro rice in northwest Bangladesh," Climatic Change, vol. 105, no. 3-4, pp. 433-453, 2011.

[8] C. S. De Silva, E. K. Weatherhead, J. W. Knox et al., "Predicting the impacts of climate change- a case study on paddy irrigation water requirements in Sri Lanka," Agricultural Water Management, vol. 93, no. 1-2, pp. 19-29, 2007.

[9] E. Elgaali, L. A. Garcia, and D. S. Ojima, "High resolution modeling of the regional impacts of climate change on irrigation water demand," Climatic Change, vol. 84, no. 3-4, pp. 441-461, 2007.

[10] G. Fischer, F. N. Tubiello, H. Van Velthuizen et al., "Climate change impacts on irrigation water requirements: effects of mitigation 1990-2080," Technological Forecasting and Social Change, vol. 74, pp. 1083-1107, 2006.

[11] J. A. Rodríguez Díaz, E. K. Weatherhead, J. W. Knox, and E. Camacho, "Climate change impacts on irrigation water requirements in the Guadalquivir river basin in Spain," Regional Environmental Change, vol. 7, no. 3, pp. 149-159, 2007.

[12] T. Yano, M. Aydin, and T. Haraguchi, "Impact of climate change on irrigation demand and crop growth in a Mediterranean environment of Turkey," Sensors, vol. 7, no. 10, pp. 2297-2315, 2007.

[13] K. Brumbelow and A. Georgakakos, "An assessment of irrigation needs and crop yield for the United States under potential climate changes," Journal of Geophysical Research: Atmospheres, vol. 106, no. D21, pp. 27383-27405, 2001.

[14] P. Döll, "Impact of climate change and variability on irrigation requirements: a global perspective," Climatic Change, vol. 54, no. 3, pp. 269-293, 2002.

[15] R. C. Izaurralde, N. J. Rosenberg, R. A. Brown, and A. M. Thomson, "Integrated assessment of Hadley center (HadCM2) climate-change impacts on agricultural productivity and irrigation water supply in the conterminous United States," Agricultural and Forest Meteorology, vol. 117, no. 1-2, pp. 97-122, 2003.

[16] M. Mkhwanazi, Assessment of Climate Change Impacts on Irrigation Requirements and Productivity of Sugarcane in Swaziland, MSc thesis, Cranfield University, Cranfield, UK, 2006.

[17] C. Rosenzweig, K. M. Strzepek, D. C. Major et al., "Water resources for agriculture in a changing climate: international case studies," Global Environmental Change, vol. 14, no. 4, pp. 345-360, 2004.

[18] T. Yano, T. Haraguchi, and M. Koriyama, "Prediction of future change of water demand following global warming in the Cukurova region Turkey," in The Final Report of the Research Project on the Impact of Climate Changes on Agricultural Production System in Arid Areas (ICCAP); Research Institute for Humanity and Nature (RIHN) of Japan and the
Scientific and Technological Research Council of Turkey (TÜBITAK)ICCAP Publication, Santa Rosa, CA, USA, 2007.

[19] T. Yano, M. Koriyama, T. Haraguchi et al., "Prediction of future change of water demand following global warming in the Cukurova region of Turkey," Proceedings of the International Conference on Water Land and Food Security in Arid and Semi-arid Regions Mediterranean Agronomic Institute Valenzano (CIHEAM-MAIB), Bari, Italy, 2005.

[20] S. Shahid and M. K. Hazarika, "Groundwater drought in the northwestern districts of Bangladesh," Water Resour. Manage.vol. 24, pp. 1989-2006, 2010.

[21] N. C. Dey, R. Saha, M. Parvez et al., "Sustainability of groundwater use for irrigation of dry-season crops in northwest Bangladesh," Groundwater for Sustainable Development, vol. 4, pp. 66-77, 2017.

[22] M. B. Hossain, M. Maniruzzaman, M. S. Yesmin et al., "Water and soil salinity dynamics and dry season crop cultivation in coastal region of Bangladesh," Indian Society of Coastal Agricultural Research, vol. 37, no. 2, pp. 24-31, 2019.

[23] D. Roy, M. U. Ahmed, and M. N. H. Mahmud, "Water management technologies for sustainable rice cultivation under changing climate," Journal of Agricultural Engineering, vol. 41, pp. 43-51, 2014.

[24] M. Maniruzzaman, J. C. Biswas, M. B. Hossain et al., "Effect of elevated air temperature and carbon dioxide levels on dry season irrigated rice productivity in Bangladesh," American Journal of Plant Sciences, vol. 9, no. 7, pp. 1557-1576, 2018.

[25] IPCC, "Intergovernmental panel on climate change. Climate change 2007: impacts adaptation and vulnerability," in Contribution of Working Group II to the Fourth Assessment Report of the Intergovernmental Panel on Climate Change, M. L. Parry, O. F. Canziani, J. P. Palutikof et al., Eds., Cambridge University Press, Cambridge, UK, 2007.

[26] P. Krishnan, B. Ramakrishnan, K. R. Reddy, and V. R. Reddy, "High-temperature effects on rice growth, yield, and grain quality," Advances in Agronomy, vol. 111, no. 3, pp. 87-206, 2011.

[27] M. R. Rahman and H. Lateh, "Climate change in Bangladesh: a spatio-temporal analysis and simulation of recent temperature and rainfall data using GIS and time series analysis model," Theoretical and Applied Climatology, vol. 128, no. 1-2, pp. 27-41, 2017.

[28] S. Cheyglinted, S. L. Ranamukhaarachchi, and G. Singh, "Assessment of the CERES-Rice model for rice production in the central plain of Thailand," The Journal of Agricultural Science, vol. 137, no. 3, pp. 289-298, 2001.

[29] R. G. Allen, L. S. Pereira, D. Raes, and M. Smith, Crop Evapotranspiration-Guidelines for Computing Crop Water Requirements-FAO Irrigation and Drainage Paper 56, Food and Agriculture Organizations of the United Nations, Rome, Italy, 1998.

[30] BRRI (Bangladesh Rice Research Institute), Annual report 2017-2018, Bangladesh Rice Research Institute, Gazipur, Bangladesh, 2018.

[31] M. Maniruzzaman, J. C. Biswas, M. B. Hossain et al., "Evaluating the CERES-Rice model under dry season irrigated rice in Bangladesh: calibration and validation," Journal of Agricultural and Crop Research, vol. 5, no. 6, pp. 96-107, 2017.

[32] D. N. Moriasi, J. G. Arnold, M. W. V. Liew, R. L. Bingner, R. D. Harmel, and T. L. Veith, "Model evaluation guidelines for systematic quantification of accuracy in watershed 
simulations," Transactions of the ASABE, vol. 50, no. 3, pp. 885-900, 2007.

[33] D. Raes, P. Steduto, T. C. Hsiao, and E. Fereres, Reference Manual of AquaCrop Model, p. 164, FAO Land and Water Division, Rome, Italy, 2012.

[34] A. Bakhsh, I. Bashir, H. U. Farid, and S. A. Wajid, "Using CERES-wheat model to simulate grain yield production function for Faisalabad Pakistan conditions," Experimental Agriculture, vol. 49, no. 3, pp. 461-475, 2013.

[35] C. J. Willmott, "On the evaluation of model performance in physical geography," in Spatial Statistics and Models, G. L. Gaile and C. J. Willmott, Eds., D. Reidel, Norwell, MA, USA, 1984.

[36] M. Hossain, S. Yesmin, M. Maniruzzaman, and J. Biswas, "Irrigation scheduling of rice (Oryza sativa L.) using CROPWAT model in the Western region of Bangladesh," The Agriculturists, vol. 15, no. 1, pp. 19-27, 2017.

[37] R. Mahmood, "Air temperature variations and rice productivity in Bangladesh: a comparative study of the performance of the YIELD and the CERES-Rice models," Ecological Modelling, vol. 106, no. 2-3, pp. 201-212, 1998.

[38] R. Guo, Z. Lin, X. Mo, and C. Yang, "Responses of crop yield and water use efficiency to climate change in the North China Plain," Agricultural Water Management, vol. 97, no. 8, pp. 1185-1194, 2010.

[39] C. Zhao, B. Liu, S. Piao et al., "Temperature increase reduces global yields of major crops in four independent estimates," PNAS, vol. 114, no. 114, pp. 9326-9331, 2017.

[40] B. A. Rani and N. Maragatham, "Effect of elevated temperature on rice phenology and yield," Indian Journal of Science and Technology, vol. 6, no. 8, pp. 5095-5097, 2013.

[41] M. B. Hossain, J. C. Maniruzzaman, M. M. Haque, and N. Kalra, "Irrigation strategy for crop production in Northwest and southwest region of Bangladesh," The Agriculturists, vol. 18, no. 2, pp. 126-139, 2020.

[42] J. T. Baker, L. H. Allen, and K. J. Boote, "Growth and yield responses of rice to carbon dioxide concentration," The Journal of Agricultural Science, vol. 115, no. 3, pp. 313-320, 1990.

[43] J. Cho and T. Oki, "Application of temperature, water stress, CO2 in rice growth models," Rice, vol. 5, no. 1, p. 10, 2012.

[44] USDA, World Agricultural Production, USDA, Washington, NJ, USA, 2020. 